\title{
PERLINDUNGAN HUKUM TERHADAP ALIRAN MENYIMPANG DI INDONESIA
}

\section{Legal Protection of Misguided Sects in Indonesia}

\author{
M. Iwan Satriawan \\ Fakultas Hukum, Universitas Lampung \\ email: i_santri@yahoo.co.id
}

\begin{abstract}
During Soeharto's adminitration which was called Orde Baru (New Orde) only five religions were admited by the government, they are Islam, Kristen Protestan, Kristen katolik, Hindu and Budha. But, since the era of the reformation in 1998, much faith has came up and developed in Indonesia, they are called "deviant" (aliran menyimpang). The existence of deviant in Indonesia, more due to different interpretations of the verses of the holy. It was also because the readings from different sources exegesis-commentaries. Efforts legal protection that has been done by the government in terms of addressing the emergence of deviant in Indonesia use two methods: by means of preventive and repressive.
\end{abstract}

Keywords : Five Faith, Deviant.

\section{abstrak}

Selama pemerintahan orde baru hanya 5 (lima) agama yang diakui oleh pemerintah yaitu Islam, Kristen Protestan, Kristen katolik, Hindu dan Budha. Akan tetapi, pasca reformasi 1998, muncul banyak aliran kepercayaan di Indonesia, yang dikemudian hari disebut dengan aliran menyimpang. Keberadaan aliran menyimpang di Indonesia lebih banyak diakibatkan berbedanya tafsir terhadap ayat-ayat suci. Hal ini juga dilatarbelakangi berbedanya sumber bacaan dari para mufasir-mufasir. Upaya perlindungan hukum yang telah dilakukan oleh pemerintah dalam hal menangani bermunculannya aliran menyimpang di Indonesia menggunakan 2 (dua) metode yaitu dengan cara preventif dan represif.

Kata Kunci: lima agama, aliran menyimpang

\section{A. Pendahuluan}

Negara Indonesia sebagai negara kepulauan yang terdiri dari banyak suku dan budaya menyebabkan pluralisme dalam hal keagamaan tidak dapat dihindarkan. Hal ini terkait juga dengan kondisi geografis dan sejarah 
masing-masing daerah sehingga satu agama di Indonesia akan dapat memunyai berbagai macam aliran.

Menyadari fakta tersebut, maka para "founding people"l dalam merumuskan UUD 1945 memberikan jaminan kebebasan bagi setiap penduduk Indonesia untuk memeluk dan menganut kepercayaannya atau keyakinannya masing-masing. Kehidupan beragama sendiri di Indonesia diatur dalam Pasal 29 ayat 2 UUD 1945 yang menyatakan bahwa "negara menjamin kemerdekaan tiap-tiap penduduk untuk memeluk agamanya masing-masing dan untuk beribadah menurut agamanya dan kepercayaannya itu".

Rumusan tersebut merupakan landasan konstitusional kedudukan agama dalam Negara Republik Indonesia dan menunjukkan bagaimana eratnya hubungan agama dan negara. Prinsip kebebasan beragama dan berkepercayaan itu merupakan pengakuan dan jaminan serta perlindungan bahwa setiap orang bebas dan merdeka menganut agama dan kepercayaan yang diyakininya.

Setelah reformasi 1998, terjadi perubahan yang sangat siginifikan terhadap bentuk ketatanegaraan Republik Indonesia, khususnya terhadap pengakuan dan penerapan HAM. Melalui Pasal 28E ayat (1) yang menyatakan "bahwa setiap orang bebas memeluk agama dan beribadah menurut agamanya, memilih kewarganegaraan, memilih tempat tinggal di wilayah negara dan meninggalkannya, serta berhak kembali."

Sedangkan pada Pasal 28E ayat (2) menyatakan bahwa setiap orang berhak atas kebebasan meyakini kepercayaan, menyatakan pikiran dan sikap, sesuai dengan hati nuraninya. Bahkan dalam UUD 1945 juga menyatakan bahwa hak beragama diakui sebagai hak dasar yang tidak dapat dikurangi dalam keadaan apapun sesuai dengan Pasal 28 I ayat (1).

Dalam perkembangannya, bunyi Pasal tersebut di atas, telah dijadikan dasar oleh beberapa golongan dengan mendirikan aliran-aliran sempalan yang menyimpang dari ajaran resmi agama asalnya. Baik dari segi muamalah maupun akidahnya. Berikut ini adalah data penganut agama dan aliran kepercayaan di Indonesia pada tahun 2009:

\section{Tabel 1}

\section{Penganut Agama dan Aliran Kepercayaan di Indonesia}

\begin{tabular}{|l|c|c|}
\hline Agama/Aliran Kepercayaan & Jumlah & \% \\
\hline Islam & 206.873 .780 & $86.10 \%$ \\
\hline
\end{tabular}

\footnotetext{
${ }^{1}$ Menurut Mahfud M. D. tidak semua perumus UUD 1945 adalah laki-laki, namun ada beberapa perempuan seperti Maria Ulfa, sehingga beliau lebih condong menyatakan sebagai founding people daripada founding father.
} 


\begin{tabular}{|l|l|l|}
\hline Katholik & 7.208 .146 & $3.00 \%$ \\
\hline Protestan & 13.695 .477 & $5.70 \%$ \\
\hline Hindu & 4.324 .887 & $1.80 \%$ \\
\hline Buddha & 2.402 .715 & $1.00 \%$ \\
\hline Konghucu & 240.272 & $0.10 \%$ \\
\hline Kepercayaan lainnya & 5.526 .245 & $2.30 \%$ \\
\hline Total & 240.271 .522 & $100 \%$ \\
\hline
\end{tabular}

Sumber:IGM.Nurdjana,2009:5

Tabel 2

Aliran Islam "Sempalan" Di Provinsi Lampung

\begin{tabular}{|c|c|c|}
\hline NO & NAMA ALIRAN & DAERAH PENYEBARAN \\
\hline 1 & $\begin{array}{lll}\begin{array}{l}\text { Alqiyah Al } \\
\text { Mushaddeq) }\end{array} & \text { Islamiyah } & \text { (Ahmad } \\
\end{array}$ & $\begin{array}{l}\text { Lambar, Bandar Lampung, } \\
\text { Lamteng, Lamut }\end{array}$ \\
\hline 2 & $\begin{array}{lll}\text { Organisasi } & \text { Istana } & \text { Kerajaan } \\
\text { Majapahit III } & & \end{array}$ & Lamtim \\
\hline 3 & Islam Riyadul Muft diin & Lamsel \\
\hline 4 & Pengajian Eksklusif & Lamsel \\
\hline 5 & Tarekat Al Ikhlash & Lamsel \\
\hline 6 & Dzikir Mushola AL Falah & Bandar lampung \\
\hline 7 & Aliran Reformasi Rosul Muhammad & $\begin{array}{lll}\text { Banjar } & \text { Agung/ } & \text { Tulang } \\
\text { Bawang } & & \\
\end{array}$ \\
\hline 8 & Aliran Syech Siti Jenar & Bandar lampung \\
\hline 9 & Ahmadiyah & $\begin{array}{ll}\text { tidak } & \text { terdekteksi } \\
\text { penyebarannya } & \end{array}$ \\
\hline 10 & Al qur'an Suci & - \\
\hline 11 & Al Wahidiyah & - \\
\hline 12 & Salamullah (Lia Eden) & - \\
\hline 13 & Mahesa Kurung Al Mukarromah & - \\
\hline 14 & Islam Sejati & - \\
\hline 15 & Agama Baha'i & - \\
\hline 16 & Ajaran Islam Baru & $\begin{array}{l}\text { Desa Sumberhadi Kecamatan } \\
\text { Melinting, Lampung Timur }\end{array}$ \\
\hline
\end{tabular}

Sumber: MUI Provinsi Lampung

Khusus untuk kepercayaan lainnya yang ada di Indonesia masih terbagi ke dalam berbagai macam aliran, baik itu yang masih terpengaruh adat istiadat setempat dalam artian membentuk kepercayaan tersendiri seperti aliran agama jawa bagi penduduk sekitar daerah pegunungan Tengger dan ada juga beberapa aliran sempalan atau menyimpang dari agama induk 
yang tidak atau belum terdeteksi oleh Departemen Keagamaan RI yang besarnya adalah $2.30 \%$ atau sekitar 5.526.245 jiwa penganutnya.

Sedangkan untuk Provinsi Lampung sendiri sebagai pusat penelitian ini telah dipetakan ada sekitar 16 (enam belas) aliran menyimpang semenjak reformasi 1998 yaitu sebagai berikut: Berdasarkan data tersebut di atas, maka dapat dikemukakan bahwa banyaknya aliran sempalan atau menyimpang yang hidup dan berkembang di Provinsi Lampung. Maka dibutuhkan upaya-upaya perlindungan dan pemberdayaan aliran ini agar tidak terjadi ketegangan dengan aliran yang lain diakibatkan saling menganggap alirannya yang paling benar. Dalam prespektif kebijakan, maka diperlukan kebijakan yang materinya untuk melindungi dan mengatasi agar antar aliran dalam agama Islam ini saling hormat menghormati tidak saling menghujat sehingga menimbulkan bentrokan antar pengikut aliran keagamaan yang merugikan bagi kehidupan beragama dan berkebangsaan.

Dalam konteks ini langkah-langkah pemberdayaan umat beragama adalah melalui pendidikan dan pemahaman berupa saling menghargai, menghormati perbedaan dan hak asasi masing-masing individu untuk menjalankan aliran keagamaannya. Kemudian diperlukan kebijakan khusus oleh pemerintah daerah dengan mengeluarkan peraturan daerah berupa perlindungan hukum terhadap aliran keagamaan yang telah hidup dan berkembang di Provinsi Lampung khususnya.

Berdasarkan hal tersebut di atas, maka dapat penulis tarik benang merah permasalahan adanya aliran menyimpang di Indonesia khususnya Provinsi Lampung adalah 1) Mengapa muncul aliran menyimpang dalam Agama Islam khususnya di Provinsi Lampung? Serta 2) Bagaimana bentuk perlindungan hukum oleh pemerintah Provinsi Lampung terhadap aliran menyimpang tersebut?

\section{B. Pembahasan}

\section{Hubungan Negara dan Agama di Indonesia}

Sebagai negara hukum (rechstaat) bukan negara kekuasaan (machstaat) maka sudah menjadi keharusan bagi semua penyelenggara negara dan pemerintahannya untuk selalu mendasarkan kebijakan yang diambil pada peraturan perundang-undangan yang berlaku. Bagi negara dengan paham negara agama (teokrasi) yang hanya mendasarkan ideologinya pada agama tertentu, maka pembuatan peraturan perundangundangan harus mengacu kitab suci agama tertentu yang menjadi agama negara. Hal mana menurut paham teokrasi, negara dan agama dipahami sebagai dua hal yang tidak dapat di pisahkan, dijalankan berdasarkan firmanfirman Tuhan, sehingga tata kehidupan masyarakat, bangsa dan negara dilakukan dengan titah Tuhan dalam kehidupan umat manusia. Oleh karena itu, paham ini melahirkan konsep "negara agama" atau agama resmi, dan 
dijadikannya agama resmi tersebut sebagai hukum positif. Konsep negara teokrasi ini sama dengan paradigma integralistik, yaitu paham yang beranggapan bahwa agama dan negara merupakan suatu kesatuan yang tidak dapat dipisahkan. dan tidak juga beraliran agama sekuler yang tidak memedulikan agama ${ }^{2}$.

Namun berbeda halnya jika mengacu pada negara yang menjadikan relasi antara agama dan negara dikemas secara sinergis bukan dikotomis yang memisahkan antara keduanya. Agama dan negara merupakan entitas yang berbeda, namun keduanya dipahami saling membutuhkan secara timbal balik, yakni agama membutuhkan negara sebagai instrumen dalam melestarikan dan mengembangkan agama, sebaliknya negara juga membutuhkan agama, karena agama juga membantu negara dalam pembinaan moral, etika dan spiritualitas. Pemahaman seperti ini disebut dengan "paradigma simbiotik" .

Suatu negara yang menganut keragaman agama, pengakuan kebebasan beragama memberikan rasa aman bagi rakyatnya, artinya tidak ada satu agama yang dijadikan agama resmi negara serta tidak juga satu agama tertentu yang dijadikan sumber moral dan hukum. Hubungan antara negara dan agama antara lain diwujudkan dengan dibentuknya Kementerian Agama dalam struktur organisasi Pemerintahan. Bentuk lain keikutsertaan pemerintah dalam persoalan agama adalah adanya pengakuan terhadap beberapa agama yang tumbuh dan berkembang di wilayah negara tersebut.

Salah satu contoh bentuk pengakuan ini melalui keluarnya Surat Edaran Menteri Dalam Negeri No.477/74054/1978 yang antara lain menyebutkan: agama yang diakui pemerintah, yaitu Islam, Katolik, Kristen/ Protestan, Hindu, Buddha dan Khonghucu. Pemerintah juga membentuk lembaga-lembaga seperti MUI, WALUBI, PGI, KWI dan HINDU DHARMA. Walaupun Negara Indonesia mengakui agama-agama tersebut di atas dan dijabarkan dalam bentuk pelayanan organ negara, akan tetapi jaminan kepada tiap-tiap orang memeluk agama di luar agama-agama tersebut tetap memperoleh perlindungan ${ }^{4}$.

Selain daripada itu, legitimasi keberagaman agama di wilayah hukum Negara Kesatuan Republik Indonesia (NKRI) serta menjalankan ibadah sesuai dengan agama dan kepercayaannya masing-masing, dilindungi secara konstitusional. Hal ini terbukti dengan bunyi Pasal 29 UUD 1945 sebagai berikut:

a. negara berdasarkan Ketuhanan Yang Maha Esa; dan

\footnotetext{
${ }_{2}^{2}$ M. Iwan Satriawan, Formalisasi Hukum Islam, Lampung Post, Jum'at 3 Februari 2012.

${ }^{3}$ Ibid.

${ }^{4}$ Budiyono, Tanggung Jawab Negara Menjamin dan Melindungi Kemerdekaan Beragama dan Berkepercayaan Berdasarkan UUD 1945, (Sebuah ringkasan Disertasi S3 UNPAD, tidak dipublikasikan, 2012), hlm. 3.
} 
b. negara menjamin kemerdekaan tiap-tiap penduduk untuk memeluk agamanya masing-masing dan untuk beribadat menurut agamanya dan kepercayaannya itu.

Jaminan keberagaman ini dipertegas lagi dalam Garis-Garis Besar Haluan Negara (GBHN) ${ }^{5}$, sebagai landasan operasionalnya. Hal ini bertujuan untuk memantapkan fungsi, peran dan kedudukan agama sebagai landasan moral dan spriritual dalam penyelenggaraan negara, serta mengupayakan agar segala peraturan perundang-undangan tidak bertentangan dengan moralmoral agama ${ }^{6}$.

Namun hal berbeda diungkapkan oleh M.Tahir Azhary $^{7}$ yang menyatakan bahwa hubungan agama, negara dan hukum dalam prespektif aldinul Islami, agama, negara dan hukum merupakan satu totalitas yang tidak mungkin dipisahkan. Agama adalah inti dari negara dan hukum dan sekaligus pula mengatur kehidupan negara dan merupakan sumber hukum bagi peraturan perundang-undangan yang berlaku dan mengikat masyarakat.

Lebih lanjut beliau mengungkapkan dalam konteks Indonesia, Islam adalah agama yang dianut mayoritas bangsa. Maka sesuai dengan teori kepentingan (public interest teory) dalam hukum tata negara, salah satu tugas dan kewajiban negara adalah mengakomodasi dan memerhatikan keinginan dan kepentingan para warganya dalam hal ini antara lain keinginan dan kepentingan umat Islam di Indonesia supaya hukum Islam berlaku secara kaffah (sempurna) di Negara Republik Indonesia ${ }^{8}$.

Namun hal berbeda diungkapkan oleh K.H Abdurrahman Wahid (Gus Dur) beliau mengungkapkan bahwa Islam harus bertindak sebagai faktor komplementer untuk mengembangkan sistem sosio-ekonomi dan politik, bukan sebagai faktor alternatif yang dapat membawa dampak disintegratif terhadap kehidupan bangsa secara keseluruhan. Dalam artian Islam harus dipandang dari fungsinya sebagai sebuah falsafah hidup yang menekankan kesejahteraan rakyat, "rahmatan lil 'alamin", tanpa melihat sistem politiknya. Jadi pendapatnya Islam dapat berfungsi secara penuh dalam kehidupan masyarakat melalui pengembangan nilai-nilai dasarnya sebagai etika dalam masyarakat. Fungsi ini bukanlah bentuk tertentu dari negara, tetapi sebuah sistem etika sosial yang ditujukan untuk membimbing masyarakat dan negara sesuai dengan martabat manusia .

\footnotetext{
${ }^{5}$ GBHN sendiri semenjak selesainya amandemen UUD 1945 pada tahun 2002 sudah tidak dipergunakan lagi dalam sistem ketatanegaraan Indonesia.

${ }^{6}$ A.Rahmat Rosyadi dan Rais Ahmad, Formalisasi Syariat Islam dalam Perspektif Tata Hukum Indonesia, (Bogor: Ghalia, 2006), hlm. 2.

${ }^{7}$ M.Tahir Azhary, Beberapa Aspek Hukum Tata Negara, Hukum Pidana, Dan Hukum Islam, (Jakarta: Kencana, 2012), hlm. 491.

${ }^{8}$ Ibid.

${ }^{9}$ Op.Cit., K.H Abdurrahman Wahid dalam Rahmat Rosyadi dan Rais Ahmad, hlm. 28-29.
} 
Dari perdebatan pola relasi agama dan negara tersebut memunculkan tiga teori, yaitu pertama paradigma integralistik (unified paradigm) yaitu paradigma yang menyatakan hubungan antara agama dan negara menyatu (integrated). Wilayah agama meliputi politik atau negara. Negara merupakan lembaga politik dan keagamaan sekaligus. Karenanya menurut paradigma ini, kepala negara adalah pemegang kekuasaan agama dan kekuasaan politik. Pemerintahannya diselenggarakan atas dasar kedaulatan ilahi (divine sovereignty), karena pendukung paradigma ini menyakini bahwa kedaulatan berasal dan berada di tangan Tuhan ${ }^{10}$. Hal ini yang kemudian disebut sebagai negara teokrasi. Dalam teori teokrasi ${ }^{11}$, disebutkan bahwa urusan negara tidak dapat dipisahkan dari urusan keagamaan. Negara berdasarkan atas ketuhanan menurut suatu agama tertentu. Negara selalu mengatur urusan agama dan mewajibkan warga negara untuk melaksanakan. Negara diatur oleh syariat agama (negara agama). Konsep negara dan agama tersebut teraplikasi dalam konsep tahta suci Vatikan, Negara Iran.

Sedangkan paham atau teori yang kedua adalah paradigma simbiotik (symbiotic paradigm) yaitu teori atau paradigma yang menyatakan agama dan negara berhubungan secara simbiotik, yakni suatu hubungan yang bersifat timbal balik dan saling memerlukan. Dalam hal ini, agama memerlukan negara karena dengan negara, agama dapat berkembang. Sebaliknya negara juga memerlukan agama, karena dengan agama negara dapat berkembang dalam bimbingan etika dan moral-spiritual ${ }^{12}$.

Kemudian paham yang ketiga adalah menganut paradigma sekularistik (secularistic paradigm) yaitu paradigma yang mengajukan pemisahan (disparitas) agama atas negara dan pemisahan negara atas agama. Dalam konteks Islam, paradigma ini menolak mendasarkan negara kepada Islam, atau paling tidak menolak determinasi Islam pada bentuk tertentu dari negara ${ }^{13}$.

Hal ini yang kemudian dinamakan negara sekuler adalah apabila negara memisahkan secara diametral antara urusan agama dan negara. Negara tidak ikut campur sama sekali terhadap urusan agama baik materi dalam artian memberikan dana khusus untuk pengembangan agama maupun non materi dalam hal pemikiran atau kebijakan yang pada akhirnya mempermudah atau melindungi agama. Jadi dalam negara sekuler urusan agama dikembalikan kepada hak individu masing-masing anggota masyarakat.

\footnotetext{
${ }^{10}$ Marzuki Wahid dan Rumadi, Fiqh Madzhab Negara, (Yogyakarta: LkiS, 2001), hlm. 23-24.

${ }^{11}$ Op.Cit., Rahmat Rosyadi, hlm. 178.

${ }^{12}$ Op.Cit., Marzuki Wahid, hlm. 26.

${ }^{13}$ Ibid., hlm. 28.
} 
Sedangkan Gede Atmadja ${ }^{14}$ menjelaskan negara sekuler adalah negara yang tidak berdasarkan ketuhanan dan tidak berdasarkan pada agama, serta memisahkan urusan agama dari negara. Negara tidak ikut campur atau memasuki domain kebebasan beragama. Warga negara bebas melaksanakan agamanya masing-masing atau tidak beragama sekalipun.

\section{Model Perlindungan Hukum di Indonesia}

Pengertian perlindungan hukum bagi rakyat berkaitan dengan rumusan dalam kepustakaan Belanda yang berbunyi "rechtsbescherming van de burgers tegen de overhead" atau dalam bahasa inggrisnya "legal protection of the individual in relation to act of administrative authorities".

Perlindungan hukum bagi rakyat sendiri merupakan konsep yang universal, dalam artian dianut dan diterapkan oleh setiap negara yang mengedepankan dirinya sebagai negara hukum (rechtsstaat). Perlindungan hukum sendiri dibedakan dalam dua macam, yaitu: perlindungan hukum preventif dan perlindungan hukum yang represif. Dalam perlindungan hukum preventif, kepada rakyat diberikan kesempatan untuk mengajukan keberatan (inspraak) atau pendapatnya sebelum suatu keputusan pemerintah mendapatkan bentuk yang tetap (definitive).

Prinsip perlindungan hukum bagi rakyat Indonesia adalah prinsip pengakuan dan perlindungan terhadap harkat dan martabat manusia yang bersumber pada Pancasila dan prinsip negara hukum yang berdasarkan Pancasila $^{15}$. Hal ini dapat diwujudkan dalam bentuk perlindungan hukum perdata maupun publik ${ }^{16}$.

Berkenaan dengan perlindungan hukum perdata kepada rakyat atas perbuatan negara, maka secara teoretik Kranenburg mengemukakan tujuh konsep berkenaan hal tersebut. Pertama, kosep negara sebagai lembaga kekuasaan yang dikaitkan dengan konsep hukum sebagai keputusan kehendak yang diwujudkan oleh kekuasaan, menyatakan bahwa tidak ada tanggung gugat negara. Kedua, konsep yang membedakan negara sebagai penguasa dan negara sebagai fiscus $^{17}$. Sebagai penguasa, negara tidak dapat digugat dan sebaliknya sebagai fiscus negara dapat saja digugat. Ketiga, konsep yang mengetengahkan kriteria sifat hak, yakni apakah suatu hak dilindungi oleh hukum publik ataukah hukum perdata. Keempat, konsep yang mengetengahkan kiteria kepentingan hukum yang dilanggar. Kelima, konsep yang mendasarkan pada perbuatan melawan hukum

\footnotetext{
${ }^{14}$ Op.Cit., Dewa Gede Atmadja, hlm. 187.

${ }^{15}$ Philipus M.Hadjon, Perlindungan Hukum Bagi Rakyat di Indonesia, (Surabaya: Peradaban, 2007), hlm. 19.

${ }^{16}$ Op.Cit., Ridwan,H.R., hlm. 213.

${ }^{17}$ Fiscus adalah kas Negara, sedangkan kalau Fiscal adalah bersangkut paut dengan pajak. Fiscaalrecht:hukum pajak atau hukum fiscal. Fiscale rechtspraak;peradilan pajak.
} 
(onrechtmatiggedaad) sebagai dasar untuk menggugat negara. Keenam, konsep yang memisahkan antara fungsi dan pelaksanaan fungsi dan ketujuh adalah konsep yang mengetengahkan asumsi dasar bahwa negara dan alatalatnya berkewajiban dalam tindak-tanduknya, apapun aspeknya (baik hukum publik maupun perdata) ${ }^{18}$.

Sedangkan untuk perlindungan hukum dalam bidang publik adalah tindakan hukum pemerintah yang menimbulkan akibat hukum dalam artian keputusan-keputusan dan ketetapan-ketetapan pemerintah yang bersifat sepihak. Dikatakan bertindak sepihak jika suatu tindakan hukum yang dilakukan pemerintah tergantung pada kehendak sepihak pemerintah.

\section{Munculnya Aliran Menyimpang di Indonesia}

Kebebasan menganut agama dan aliran kepercayaan merupakan salah satu hak fundamental yang harus dilindungi oleh negara. Namun dibeberapa bagian negara di dunia, kebebasan beragama menjadi salah satu hal yang sering dilanggar pelaksanaannya oleh negara. Tidak hanya di beberapa negara Eropa yang seringkali menyatakan sebagai negara penegak HAM dan demokrasi melainkan juga di beberapa negara Asia.

Munculnya aliran menyimpang dalam beragama di Indonesia sebenarnya sudah ada semenjak zaman penjajahan Belanda, dan semakin besar di saat kran reformasi dan demokrasi dibuka sebesar-besarnya di Indonesia. Pada waktu era orde baru, pembatasan pada kebebasan beragama hanya diberikan pada 5 (lima) aliran agama dan aliran kepercayaan. Hal ini berakibat pada sebagian masyarakat Tionghoa bergabung kepada agama Budha atau Nasarani. Sedangkan bagi penganut Islam Kejawen diberi label sebagai aliran kepercayaan oleh pemerintah orde baru.

Tindakan pemerintah orde baru dengan tangan besinya dalam membatasi hak masyarakat dalam beragama akhirnya membawa dampak meledaknya kebebasan berkeyakinan dan beragama pasca bergulirnya reformasi 1998. Di mana kebebasan beragama dibuka lebar-lebar membuat setiap aliran sempalan menampakkan diri. Tidak hanya dalam Islam saja, namun hampir semua agama di Indonesia menghasilkan aliran sempalan. Hal ini kemudian menimbulkan kegaduhan dalam masyarakat yang baru mendapatkan eforia kebebasan namun tidak siap berbeda dengan masyarakat lain dalam beribadah. Hampir semua aliran sempalan di awal reformasi menampakkan dirinya dengan terang-terangan. Mulai dari munculnya nabi baru, kiblat baru hingga sholat dengan Bahasa Indonesia ${ }^{19}$.

\footnotetext{
${ }^{18}$ Philipus M. Hadjon dalam Ridwan. H.R, Hukum Administrasi Negara, (Yogyakarta: UII Press), hlm. 213-214.

${ }^{19}$ Sholat dengan Bahasa Indonesia dimunculkan oleh Gus Yusman Roy di Lawang Malang pada tahun 2006.
} 
Sifat cauvinisme atau merasa paling benar sendiri semakin mengemuka di tengah-tengah masyarakat. Fenomena ini berakibat pada terjadinya bentrok fisik antar pemeluk agama yang berakibat pada munculnya disitegrasi bangsa.

Pada tahun 1689, William Orange, seorang Protestan berhasil melakukan kudeta dan mendirikan pemerintahan baru di Inggris. Dalam kebijakan agamanya, kebebasan beragama hanya diberikan kepada golongan Protestan, sedangkan penganut sekte Kristen lainnya diberangus. Bahkan para penganut Katolik ditindas selama 150 tahun $^{20}$.

Perbedaan dalam menafsirkan ajaran agama menjadi salah satu penyebab munculnya berbagai aliran dalam agama. Selain itu praktekpraktek bernuansa religius yang sebenarnya menyimpang dari ajaran agama asalnya menjadi tujuan bagi beberapa masyarakat yang merasa putus asa dengan masa depannya pasca terjadinya krisis ekonomi berkepanjangan di Indonesia.

\section{Bentuk Perlindungan Hukum Negara terhadap Kebebasan Beragama}

Dalam literatur tentang kebebasan kemerdekaan atau kebebasan beragama, dikenal "Empat Kebebasan" (The Four Freedoms) yang diperkenalkan oleh Presiden Amerika Franklin D. Roosevelt, yaitu 1) kebebasan berbicara dan mengeluarkan pendapat (freedom of speech and expression); 2) kebebasan beragama atau beribadat menurut cara agama masing-masing (freedom of religion, freedom to worship God in his own way); 3) kebebasan dari kemelaratan, kemiskinan (freedom from want); serta 4) kebebasan dari ketakutan (freedom from fear) ${ }^{21}$.

Sedangkan dalam agama Islam sendiri sebagai agama mayoritas di Indonesia menurut Syekh Syaukat Hussain menafsirkan Islam tidak pernah membelenggu gerak pikiran sehat yang bersuha menggapai hakekat dan yang menggelitik keraguan sebagai jembatan untuk sampai pada keyakinan. Nabi Muhammad telah membebaskan pikiran dari belenggu Jahiliyah dan membawanya melampaui alam kasat mata berjalan menuju alam-alam gaib sampai ke alam yang tidak nampak oleh mata telanjang dan tidak terlintas dalam benak manusia ${ }^{22}$.

\footnotetext{
${ }^{20}$ Suhelmi sebagaimana dikutip oleh Muhammad Alim, Asas-asas Negara Hukum Modern dalam Islam, (Yogyakarta: LkiS, 2010), hlm. 157.

${ }^{21}$ Ibid., hlm.157.

${ }^{22}$ Syekh Syaukat Hussain sebagaimana dikutip oleh Ahmad Sukardja, Hukum Tata Negara dan Hukum Administrasi Negara Dalam Prespektif Fikih Siyasah, (Jakarta: Sinar Grafika, 2010), hlm. 5.
} 
Indonesia sebagai negara hukum pancasila telah mengatur kebebasan beragama dan berkeyakinan dalam UUD 1945. Hal ini sebagaimana bunyi pasal 29 (2) yang menyatakan:

"Negara menjamin kemerdekaan tiap-tiap penduduk untuk memeluk agamanya masing-masing dan untuk beribadah menurut agamanya dan kepercayaannya itu."

Berdasarkan bunyi pasal tersebut, maka penyebaran semangat hormat menghormati dan toleransi dalam beragama di Indonesia mendapatkan momentumnya tatkala K.H Abdurrahman Wahid menjabat sebagai Presiden RI ke-4. Beliau tidak hanya sekedar memerintahkan jajarannya untuk bersikap toleran melainkan juga dicontohkan sendiri dalam segala tindakan dan perbuatan beliau selama menjabat menjadi Presiden dengan mengesahkan Konghucu sebagai agama ke-6 di Indonesia dan menjadikan Imlek sebagai hari libur nasional.

Seiring dengan semakin sadarnya masyarakat Indonesia atas keberagaman, maka berbagai usaha telah dilakukan oleh pemerintah untuk semakin meningkatkan kehidupan toleransi antar umat beragama. Upayaupaya tersebut dapat penulis bagi 2 (dua) yaitu, upaya preventif atau pencegahan melalui pembuatan legislasi tentang perlindungan hukum bagi kebebasan beragama dan mengumpulkan berbagai informasi mengenai penyebab aliran menyimpang. Setelah data lengkap kepada pelaku dapat diundang untuk berdialog atau konsultasi serta dapat pula dipanggil untuk dimintai keterangan, kemudian juga melihat langsung tempat kegiatan dilakukan $^{23}$. Selain itu didorongnya peningkatan kegiatan FKUB (Forum Kerukunan Umat Beragama) di setiap daerah untuk selalu mengadakan diskusi berkenaan dengan peningkatan budaya toleransi antar umat beragama.

Kedua adalah dengan melakukan upaya represif atau tindakantindakan untuk menanggulangi kasus-kasus yang telah terjadi. Usaha penanggulangan ditempuh dengan 2 (dua) cara yaitu ${ }^{24}$ :

a. penindakan yang bersifat administratif yaitu Polri bekerjasama secara fungsional dengan instansi lain melalui Bakorpakem, misalnya masalah SARA yang berkaitan dengan penodaan suatu agama sudah tentu banyak melibatkan Departemen Agama;

b. penindakan yustisiil yaitu secara fungsional Polri sesuai peraturan perundang-undangan melakukan tugas-tugas penyelidikan dan penyidikan terutama kasus-kasus dari aliran kepercayaan menyimpang yang melakukan tindak pidana umum.

\footnotetext{
${ }^{23}$ Sebagaimana diolah dalam IGM Nurdjana, , Hukum dan Aliran Kepercayaan Meyimpang di Indonesia, (Yogyakarta: Pustaka Pelajar, 2009), hlm. 292.

${ }^{24}$ Ibid.,hlm. 293-294.
} 


\section{Penutup}

\section{Simpulan}

Berdasarkan pembahasan permasalahan tersebut di atas, maka dapat penulis tarik benang merah sebagai kesimpulan adalah keberadaan aliran menyimpang di Indonesia lebih banyak diakibatkan berbedanya tafsir terhadap ayat-ayat suci. Hal ini juga dilatarbelakangi berbedanya sumber bacaan dari para mufasir-mufasir. Upaya perlindungan hukum yang telah dilakukan oleh pemerintah dalam hal menangani bermunculannya aliran menyimpang di Indonesia menggunakan 2 (dua) metode yaitu dengan cara preventif dan represif.

\section{Saran}

a. diperlukan upaya untuk terus melakukan komunikasi dengan berbagai macam umat beragama untuk meminimalisir terjadinya tindakan destruktif yang menjurus anarkis dari masyarakat akibat dari berbedanya pemahaman dalam beragama;

b. aparat keamanan dalam hal ini Polri didorong untuk selalu siap siaga dan meningkatkan badan intelejennya dalam hal menekan tindakan main hakim sendiri oleh masyarakat ketika menyikapi berbedanya tafsir agama yang timbul dan berkembang didalamnya.

\section{Daftar Pustaka}

\section{A. Buku}

Alim, Muhammad, 2010, Asas-asas Negara Hukum Modern dalam Islam, Yogyakarta: LkiS.

Azhary, M, Tahir, 2012, Beberapa Aspek Hukum Tata Negara, Hukum Pidana, Dan Hukum Islam, Jakarta: Kencana.

Fuady, Munir, 2009, Teori Negara Hukum Modern, Jakarta: Refika Aditama.

H, R, Ridwan, Hukum Administrasi Negara, Yogyakarta: UII Press.

Hadjon, Philipus M, 2007, Perlindungan Hukum Bagi Rakyat di Indonesia, Surabaya: Peradaban.

Huda, Ni'matul, 2005, Hukum Tata Negara Indonesia, Jakarta: Rajawali Press.

Nurdjana, IGM, 2009, Hukum dan Aliran Kepercayaan Meyimpang di Indonesia, Yogyakarta: Pustaka Pelajar.

Rishan, Idul, 2012, Komisi Yudisial Suatu Upaya Mewujudkan Wibawa Peradilan, Yogyakarta: Genta. 
Rosyadi, A, Rahmat dan Ahmad, Rais, 2006, Formalisasi Syariat Islam dalam Perspektif Tata Hukum Indonesia, Bogor: Ghalia.

Sukardja, Ahmad, 2012, Hukum Tata Negara dan Hukum Administrasi Negara Dalam Prespektif Fikih Siyasah, Jakarta: Sinar Grafika.

Wahid, Marzuki dan Rumadi, 2001, Fiqh Madzhab Negara, Yogyakarta: LkiS.

Yusdiansyah, Efik, 2010, Implikasi Keberadaan Mahkamah Konstitusi terhadap Pembentukan Hukum Nasional dalam Kerangka Negara Hukum, Bandung: Lubuk Agung.

\section{B. Jurnal, Disertasi dan Surat Kabar}

Budiono, 2012, Tanggung Jawab Negara Menjamin dan Melindungi Kemerdekaan Beragama dan Berkepercayaan Berdasarkan UUD 1945, Sebuah ringkasan Disertasi S3 UNPAD.

Mukhlis, Dekontruksi Paradigma Ber-demokrasi dan Ber-Nomokrasi dalam sistem Ketatanegaraan Indonesia, Jurnal Konstitusi Universitas Trunojoyo, Volume II No.1, Juni 2011.

Satriawan, M. Iwan. Formalisasi Hukum Islam, Lampung Post, Jum'at 3 Februari 2012. 